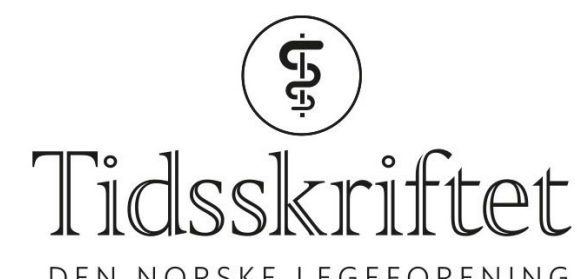

DEN NORSKE LEGEFORENING

\title{
Ola Lilleholt
}

MINNEORD

MAGNE NYLENNA

JON HILMAR IVERSEN

FRODE HEIAN

ØYSTEIN PEDERSEN

Allmennlegen, entusiasten og forbildet Ola Lilleholt døde 8. juli 2019 etter lang tids sykdom, 77 år gammel.

Som kommunelege i Rindal ble Ola en legende: arbeidsom, omsorgsfull, kunnskapsrik og alltid faglig oppdatert. Etter flere tiår som allmennlege i Halsa, Surnadal og Rindal, karakteriserte han seg selv som spesialist på nordmøringer, men han var spesialist på så mangt. Han var et uvanlig begavet multitalent, det som på den delen av landet kalles et «flogvit». Han var belest og bereist, allsidig og nysgjerrig.

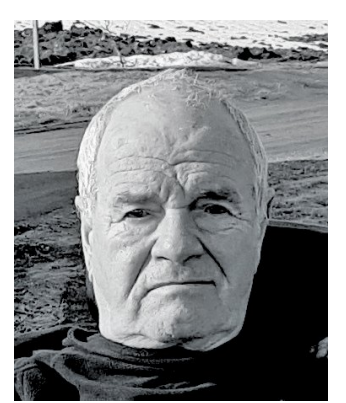

Han så tidlig potensialet for digitale hjelpemidler i helsetjenesten, og ble en EDB-pioner. Han var sentral i etableringen av Nidaroskongressen, som i år arrangeres for 16. gang, og holdt i mange år EDB-verksted for allmennlegene der. Lenge før internett åpnet kommunikasjonsmuligheter over hele verden, skapte Ola sitt eget internasjonale, faglige nettverk. Han var aktiv i internasjonale allmennlegeorganisasjoner, abonnerte på en rekke tidsskrifter og hadde faglig kontakt med kolleger i mange land og på mange språk. Ola var alltid i forkant, bredt orientert også innen kunst og kultur, og delte raust av sin kunnskap. Slik ble han til stor inspirasjon, særlig for yngre kolleger.

Ola Lilleholt var ideologisk forankret i KOPF-ideologien. Han ikke bare trodde på en kontinuerlig, omfattende, personlig og forpliktende legetjeneste, men omsatte også ideologien til praksis. Gjennom organisasjonsarbeid i inn- og utland, blant annet som leder av Norsk selskap for allmennmedisin, bidro han sterkt til primærhelsetjenestens vekst og 
utvikling i Norge på 1980- og 1990-tallet. Han var med på å organisere utplassering av medisinstudenter i kommunehelsetjenesten, og han var veileder for spesialistkandidater i allmennmedisin.

Ola var den naturlige leder av redaksjonen av Utposten, et blad for norsk allmenn- og samfunnsmedisin, i 1983-87. Årene i Utposten-redaksjonen med Ola var formgivende for oss som fikk arbeide sammen med ham, og ble for noen av oss avgjørende for karrierevalget senere i livet. Redaksjonsmøtene i Rindal med faglige diskusjoner i sene nattetimer huskes som stjerneskudd på en ellers lys himmel.

Olas siste år på sykehjem etter flere hjerneslag ble tunge, og vi har ofte savnet hans kloke kommentarer til tidsaktuelle problemer. På vegne av mange kolleger, og langt flere pasienter, takker vi for et livsverk som har satt varige spor.

Publisert: 23. september 2019. Tidsskr Nor Legeforen. DOI:10.4045/tidsskr.19.0475

(C) Tidsskrift for Den norske legeforening 2020. Lastet ned fra tidsskriftet.no 